\title{
AOR
}

Selected Papers of \#AolR2021:

The 22nd Annual Conference of the

Association of Internet Researchers

Virtual Event / 13-16 Oct 2021

\section{IMAGINING ALTERNATIVE MEDIATED FUTURES? REFLECTIONS ON EXPERIMENTAL WORKSHOPS WITH YOUNG PEOPLE}

\author{
Minna Vigren \\ Aalto University, Finland
}

Imagining alternatives to our thoroughly-networked contemporary everyday life is rare and, when attempted, not easy. This observation resonates with previous studies that show people share a sense of resignation towards their agency with regards to the digitally mediated conditions of daily life (Markham, 2020; Saariketo,2020). What is more, it seems that the notion of 'ordinary' people having limited chances to influence structural conditions has become universal. This hegemonic situation, to apply the critical definition of Stuart Hall (1983/1996), is reflected in two major ways. First, people adapt to prevailing sociotechnical arrangements even when they criticize them explicitly. Second, it appears nearly impossible to project mediated futures in ways that would challenge the dominant ideological tendencies and question existing power relations.

In our research project, we tackled the latter problem by developing an 'Imagining Workshop' method and applying it in an experimental study with young people. In this paper, we present methodological reflections based on these imagining experiments, including the challenges that became apparent during the workshops. The theme of the conference, 'independence', is imbued in the conceptualization of the activity of imagining as a prec(ar)ious agentive capacity inherent in humans as well as in our viewing the 'counter-hegemonic' mobilization of this capacity as a prerequisite for the development of more just society for all humans and non-humans.

Our paper contributes to nascent research that explores and experiments with so-called speculative methods in the field of critical media and infrastructure studies. We are interested in whether the dynamic of hegemony that actualizes in mediated daily practices can be questioned, and alternatives imagined to 'how things are'. In line with Dunne \& Raby's (2013) ideas of speculative design, we observe an urgent need to create spaces that afford discussion and encourage debate about alternatives; we also agree that there is specific potential in speculation to act as a "catalyst for collectively redefining our relationship to reality" (ibid.: 2). Our key methodological question thus is: "how could we as researchers create interventionist methods to spark imagination and inspire (self-)reflective thinking in people about their mediated everyday life?"

Suggested Citation (APA): Vigren, M. (2021, October). Imagining Alternative Mediated Futures? Reflections on Experimental Workshops with Young People. presented at AolR 2021: The 22nd Annual Conference of the Association of Internet Researchers. Virtual Event: AolR. Retrieved from http://spir.aoir.org. 
Theoretically, we find the concept 'infrastructuration' pertinent for grasping how networked media technologies contribute to the constitution of the everyday as selfevident. In a sense, it is precisely the hegemonic process of infrastructuration that 'speculative fiction' and other speculative methods are most crucially directed at. The notion refers to the phenomenon in which internet connections and 'smart' devices have become inextricable and unquestioned parts of daily practices (see, e.g., Paasonen, 2015; Saariketo, 2020; Slota \& Bowker, 2017). In the process of infrastructuration, the whole notion that there could be alternatives to prevailing circumstances sinks into oblivion, which, in turn, shrinks the capacity to imagine alternatives (see also Feenberg, 2011). In sum, infrastructuration of media and information technologies refers to their merging into society's fundamental structures, the crucial role of these technologies and our automated relations with them only becoming perceivable when they break down or operate insufficiently (Star \& Ruhleder, 1996).

A major challenge for critical research is that, in practice, people have scant possibilities to question the sociotechnical conditions of their daily life and (inter)actions. Nor are there ready-to-hand methods available for us researchers with which to initiate reflection on the domineering imaginaries of media technologies and how these imaginaries actually position people (see also Hall, 1983/1996). Discussing this methodological dilemma should be included in any empirical research project that commits itself to emancipatory knowledge interest.

In our paper, we address this and other methodological challenges through selfreflection on a case study in which we used an 'Imagining Workshop' method. In the workshops we wanted to enable young people to distance themselves from the selfevident aspects of their mediated everyday life and encourage them to imagine jointly alternative mediated futures. We invited participants (aged 14-18) to create playfully mundane scenes situated in the year 2030. We worked with 24 youngsters and two partners from the media sector. In designing the workshops, we used the results of an online survey $(n=436)$ that was conducted at the beginning of the project in the autumn 2020.

A major observation from the workshops, and one that fosters hope for the future, concerns the flexibility of imagining as a joint activity. While collectively projecting alternatives to the mediated everyday life proved challenging for the participants, it sparked vibrant discussions on the bleaker aspects of contemporary networked society. It remains for future empirical research to probe further the critical potential inherent in the collective exercise of human imaginative capacities. One challenge we observed relating to this is that the act of imagining is rooted in lived experiences of the past and does not necessarily result in the expression or co-production of counter-hegemonic narratives of the future. Hence, imagining alternatives as a crucial component of 'critical agency' (Rebughini, 2018) and a prerequisite for sociotechnical transformation requires us to distinguish the multiple nuances of imagining as an individual and joint activity.

As for the actual transformative potential of young people imagining together in playful research settings, an experimental study with a handful of participants can produce little that could be straightforwardly directly generalized. Nonetheless, our study also 
highlighted some important issues in the 'what' of imagining. First, young people have concerns about their mediated everyday lives that emphasize the need to actively seek alternatives to 'how things are'. The main concerns included the need for 1) managing better their own media use better in order to not 'be hooked' and to enable disconnection, 2) having safe and trustable online spaces free from with disinformation, and hateful content or behavior, 3) better privacy, and control over features which enable dataveillance and unwanted algorithmic governance, and 4) devices that are durable, manufactured in a fair and sustainable manner, including possibilities for repair and reuse.

\section{References}

Dunne, A. \& Raby, F. 2013. Speculative Everything: Design, Fiction, and Social Dreaming. Cambridge: MIT Press.

Feenberg, A. 2011. Agency and citizenship in a technological society. Lecture at IT University of Copenhagen. Available at: https://www.sfu.ca/ andrewf/copen5-1.pdf

Hall, S.1983/1996. The problem of ideology: Marxism without guarantees. In Stuart Hall. Critical Dialogues in Cultural Studies, edited by D. Morley \& K-H Chen, 25-46. New York: Routledge.

Markham, A. 2020. The limits of the imaginary: Challenges to intervening in future speculations of memory, data, and algorithms. New Media \& Society. https://doi.org/10.1177\%2F1461444820929322

Paasonen, S. 2015. "As networks fail: Affect, technology, and the notion of the user". Television \& New Media 16(8): 701-716.

Rebughini, P. 2018. Critical agency and the future of critique. Current Sociology 66(1), 3-19.

Saariketo, M. 2020. Kuvitelmia toimijuudesta koodin maisemissa (Imaginaries of Agency in the Landscapes of Code). PhD Dissertation, Tampere University Finland. https://trepo.tuni.fi/handle/10024/120383

Slota, S. C. \& Bowker, G. C. 2017. "How infrastructures matter". In The Handbook of Science and Technology, edited by U. Felt, R. Fouché, C. A. Miller \& L. Smith-Doerr, 529-554. 4. edition. Cambridge, MA \& London: The MIT Press.

Star, S. L. \& Ruhleder, K. 1996. "Steps toward an ecology of infrastructure: Design and access for large information spaces". Information Systems Research 7(1): 111-134. 